Jurnal Hukum Mimbar Justitia

Fakultas Hukum Universitas Suryakancana

Vol. 5 No. 1 - Juni 2019, hlm. 49-72.

ISSN: 2477-5681 (Cetak), ISSN: 2580-0906 (Online)

Open Access at: https://jurnal.unsur.ac.id/jmi

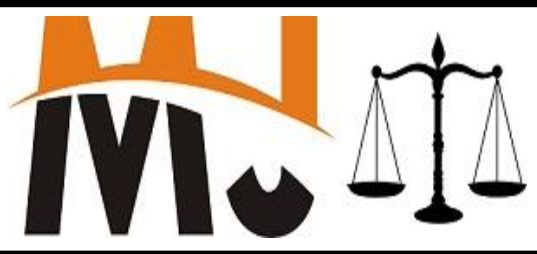

\title{
OPTIMALSASI PERAN PEMERINTAH DAERAH DALAM PERUNDUNGAN HUKUM TERHADAP BERAS BERDASARKAN KONSEP KEDAULATAN PANGAN DI INDONESIA
}

\section{Rendi Aridhayandi \\ Mahasiswa Sekolah Pascasarjana Doktor Ilmu Hukum Universitas Katolik Parahyangan Bandung E-mail: mrendiaridhayandi.1991@gmail.com}

\begin{tabular}{|l|l|l} 
Masuk: Maret 2019 & Penerimaan: April 2019 & Publikasi: Juni 2019
\end{tabular}

\begin{abstract}
ABSTRAK
Sebagai pangan pokok di Indonesia, ketersediaan beras perlu diupayakan berlanjut sampai kapanpun. Karena pertanian masih menjadi sumber mata pencaharian mayoritas angkatan kerja di Indonesia. Oleh karena itu kehadiran pemerintah sangat diperlukan, pemerintahan dapat di bedakan menjadi pemerintah pusat dan pemerintah daerah. Dalam UUD 1945 Pasal 18A ayat (1) menyebutkan hubungan wewenang antara pemerintah pusat dan pemerintahan daerah provinsi, kabupaten, dan kota, atau antara provinsi dan kabupaten dan kota, diatur dengan undang-undang dengan memperhatikan kekhususan dan keragaman daerah. Otonomi daerah menjadi salah satu wujud kebebasan bagi daerah untuk terlibat dalam merancang aktivitas politik dan pemerintahan di tingkat lokal guna menguatkan kekuasaan pemerintah pusat secara nasional. Dengan demikian peran pemerintah daerah sangat penting untuk urusan ketersediaan beras dengan adanya kewenangan otonomi daerah. Pemerintah daerah dengan otonomi daerah dapat secara bebas untuk mendesain suatu wilayahnya guna mendukung pemerintah pusat menuju ketahanan pangan.

Undang-Undang No. 18 tahun 2012 tentang Pangan menyebutkan persoalan pangan ditujukan untuk mencapai tiga hal sekaligus yaitu kedaulatan pangan, kemandirian pangan, dan katahanan pangan. Presiden Jokowi bahwa: "Ketahanan pangan merupakan sesuatu yang berbeda dari kedaulatan pangan. Ketahanan pangan hanya ketersediaan bahan pangan (logistik) di gudang dan di pasar terlepas dari asal apakah dari impor atau dari yang diproduksi secara lokal. Kedaulatan pangan berarti bahwa kita memproduksi dan memasarkan bahan makanan kita sendiri, sementara surplus produksi diekspor". Disini terlihat bahwa kedaulatan pangan bermakna lebih dalam dibanding ketahanan pangan. Dengan demikian optimalisasi pemerintah daerah guna mewujudkan kedaulatan pangan dapat berupa: 1. Reforma agraria (perlindungan lahan dengan melakukan suatu regulasi penataan ruang); 2 . Perlindungan hukum kepada petani (dengan membuat regulasi yang tujuannya mensejahterakan petani); 3. Ketersediaan bibit, pupuk dan alat-alat produksi pendukung lainnya; 4. Mendaftarkan merek dan indikasi geografis produk pertanian ke Direktorat Jenderal Kekayaan
\end{abstract}


M. Rendi Aridhayandi

Jurnal Hukum Mimbar Justitia

Vol. 5 No. 1 - Juni 2019

Intelektual Kementrian Hukum dan Hak Asasi Manusia Republik Indonesia; 5. Pengaturan harga, mutu produk dan pangsa pasar suatu produk pertanian.

Kata Kunci: Beras; Kedaulatan Pangan; Ketahanan Pangan; Pemerintah Daerah.

\begin{abstract}
As a staple food in Indonesia, the availability of rice are needed to continue until whenever. Because agriculture is still the source of livelihood of the majority of the workforce in Indonesia. Hence the presence of the government is necessary, governments can differentiate into central government and local governments. In UUD 1945 Pasal 18A ayat (1) mentions the relationship of authority between the central government and provincial government, counties, and cities, or between provinces and districts and cities, regulated by law with due regard to the specificity and diversity of the area. Regional autonomy is one manifestation of freedom for the regions to be involved in designing the activity of politics and government at the local level in order to strengthen the power of national government. Thus the role of local government is very important to the affairs of the availability of rice in the presence of local autonomy. The local government and regional autonomy can be free to design a territory in support of the central government towards food security.

Undang-Undang No. 18 tahun 2012 tentang Pangan mentions the issue of food intended to achieve three things at once, namely food sovereignty, food self-sufficiency and food security. President Jokowi that: "Food security is distinct from food sovereignty. Food security is simply the availability of foodstuffs (logistics) in the warehouse and on the market irrespective of origin whether imported or locally produced. Food sovereignty means that we manufacture and market our own groceries, while surplus production is exported ". Here we can see that food sovereignty is significantly deeper than food security. thus, the optimization of local governments in order to achieve food sovereignty can be: 1. the agrarian reform (land protection by performing a spatial planning regulations); 2. the legal protection to farmers (by making regulations that aim the welfare of farmers); 3. the availability of seeds, fertilizers and tools supporting production; 4. Registering brands and geographical indications of agricultural products to the Directorate General of Intellectual Property Ministry of law and Human Rights Republic of Indonesia; 5. setting the price, product quality and market share of an agricultural product.
\end{abstract}

Keywords: Food Security; Food Sovereignty; Rice; Regional Government. 


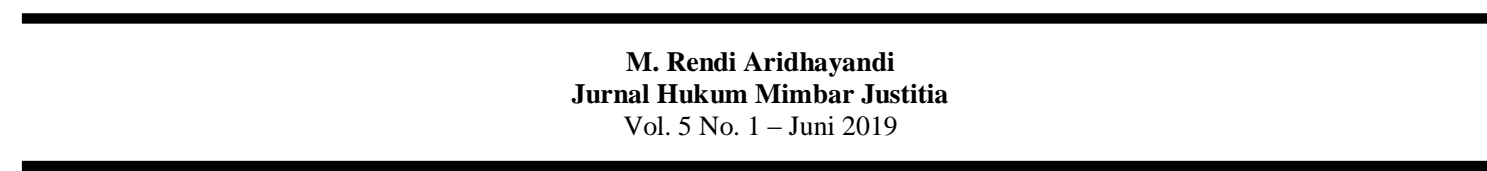

\section{PENDAHULUAN}

Pertanian masih menjadi sumber mata pencaharian mayoritas angkatan kerja di Indonesia. Pembangunan pertanian bertujuan untuk meningkatkan pendapatan dan taraf hidup petani, pertumbuhan kesempatan kerja dan berusaha, meningkatkan gizi dan ketahanan pangan rumah tangga, dan mengentaskan kemiskinan di pedesaan. ${ }^{1}$

Beras adalah hasil olahan dari produk pertanian yang di sebut padi (Oryza sativa L.), tidak memiliki dokumen tertulis yang menyebutkan sejarah penggunaannya sebagai bahan makanan. Akan tetapi, yang pasti manusia telah memanfaatkannya sejak ribuan tahun yang lalu. Menurut Vries, orang Indonesia setidaknya telah lebih dari 2.000 tahun membudidayakan padi dengan teknologi tanah jenjang (terracering) disertai dengan pengairan. Jadi dengan teknologi sederhana (yang biasa disebut primitif) tentunya padi

1 Roosganda Elizabeth, 2008, Peran Ganda Wanita Tani dalam Mencapai Ketahanan Pangan Rumah tangga di Pedesaan, Puslitbang Tanaman Pangan, Buletin Iptek Tanaman Pangan Vol. 3, No. 1, hlm. 60. telah dibudidayakan jauh sebelumnya. Satu bukti arti padi dalam kehidupan orang Indonesia khususnya penduduk Pulau Jawa, sejak zaman purba dan masih mengakar sampai kini ialah adanya mitos dalam budaya masyarakat petani padi bahwa selamatnya tanaman padi dari kegagalan atau keberhasilan tanaman adalah berkat lindungan dan berkah dari tokoh supranatural Dewi Sri (istilah Jawa) atau Dewi Pohaci (istilah Sunda), dan sebaiknya apabila terjadi kegagalan adalah akibat ulah hewan siluman berbentuk babi hutan atau serangga

bernama Kalagumarang atau Kumalagarang. ${ }^{2}$

Selaras dengan itu

Koerniatmanto Soetoprawiro dalam keterangan Foto Sampul Buku Hukum Agribisnis dan Agroindusti (...tidak bisa dilepaskan dari tradisi agraris di Jawa beserta mitos dan legenda yang melingkupinya. Padi bagi masyarakat Jawa adalah buah kemurahan Dewi

2 Muhamad Khumaidi, 2008, Beras Sebagai Pangan Pokok Utama Bangsa Indonesia, Keunikan dan Tantangannya dalam Buku Pemikiran Guru Besar Institut Pertanian Bogor (IPB) Perspektif IImu-IImu Pertanian dalam Pembangunan Nasional, Penebar Swadaya dan IPB Press, Jakarta, hlm. 179. 


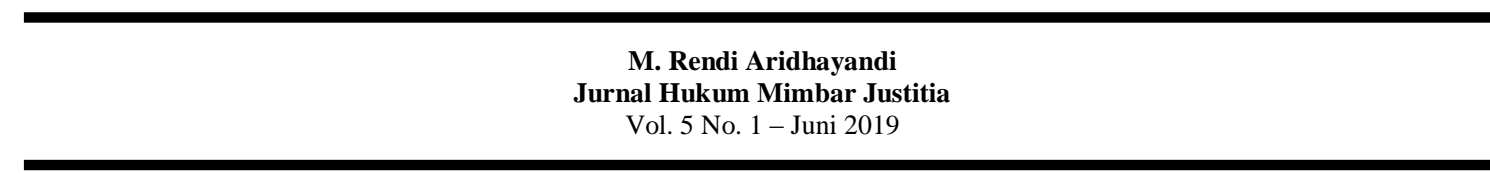

Kesuburan atau Dewi Sri atau bahkan dianggap sebagai pengejawantahan dari Dewi Sri sendiri. Oleh karena itulah padi diperlakukan secara istimewa. Pemanenan dengan menggunakan alat yang berupa ani-ani hanya dapat dilakukan dengan memotong batang padi setangkai demi setangkai. Proses ini dianggap sebagai bentuk penghargaan terhadap Dewi Sri...). ${ }^{3}$

Selanjutnya, yang disebut pangan pokok ialah pangan yang muncul dalam menu sehari-hari, mengambil porsi terbesar dalam hidangan dan merupakan sumber energi terbesar. Pangan pokok utama ialah pangan pokok yang dikonsumsi oleh sebagian besar penduduk serta dalam situasi

3 Koerniatmanto Soetoprawiro, 2016, Dalam Keterangan Foto Sampul (Gambar Reproduksi dari Buku Berjudul CameraBeelden van Sumatra, Java, Bali, Karya KT. Satake yang dipublikasikan di Surabaya tahun 1935 serta dibuat dan dicetak di Kota Middlesbrough, Inggris oleh Hood \& Co. Ltd,-Sartono) Hukum Agribisnis dan Agroindusti (Buku 1: Pengaturan dan Perlindungan Hukum atas Proses Agribisnis dan Agroindustri)-(Buku 2: Pengaturan dan Perlindungan Hukum atas Produk-Produk Pertanian), Unpar Press, Bandung, tanpa halaman. normal tidak dapat diganti oleh jenis komoditas lain. ${ }^{4}$

Sebagai pangan pokok utama bangsa Indonesia yang berawal sejak zaman purba dan tersedianya beras perlu diupayakan berlanjut sampai kapanpun karena merupakan faktor penentu (determinan) terpenuhinya kecukupan pangan dan gizi, dipertahankannya kultur kehidupan bangsa yang berwawasan adil dan makmur (Gemah Ripah Lohjinawi), serta kelestarian serasinya dinamika ekosistem tropik. ${ }^{5}$

Pembudidayaan

padi 52 memerlukan berbagai persyaratan yang keberhasilannya dipengaruhi oleh apa yang disebut faktor produksi, yaitu tenaga kerja, lahan (habitat), modal, manajemen (cara pengelolaan) dan norma sosio-budaya. Kemudian setelah dipanen faktor penentunya adalah penanganan pascapanen, yaitu pengolahan, pengepakan, penyimpanan, pengangkutan, yang dilanjutkan dengan faktor konsumsi,

\begin{tabular}{l}
\hline Muhamad Khumaidi, 2008, Beras Sebagai \\
Pangan Pokok Utama Bangsa Indonesia..., \\
Op.Cit, hlm. 180. \\
Ibid, hlm. 183.
\end{tabular} 
M. Rendi Aridhayandi

Jurnal Hukum Mimbar Justitia

Vol. 5 No. 1 - Juni 2019

yaitu pertambahan jumlah penduduk, peningkatan taraf hidup, dan perubahan pola konsumsi pangan. ${ }^{6}$

Ketersediaan beras di gudang Bulog kerap di jadikan basis ketahanan pangan di level Propinsi maupun Kabupaten. Hal ini mengidikasikan pengutamaan beras sebagai indikator ekonomi nasional. Dominasi beras atas sumber daya pangan lainnya di Indonesia dapat ditemukan dalam istilah-istilah lokal seperti "palawija" (Sansekerta, phaladwija) yang harfiahnya berarti sesuatu yang bukan beras (sekunder) atau pangan kelas dua, sesuatu yang terkonstruksikan secara budaya (culturally constructed). Beras telah menjadi sumber pangan dominan yang tercermin dari $50 \%$ total konsumsi nasional ${ }^{7}$. Hari ini, 96\% penduduk Indonesia makan beras ketimbang sumber pangan lainnya. ${ }^{8}$

\section{Oleh karena itu peran Pemerintah} sangat penting untuk ketersediaan

Ibid, hlm. 184.

7 Van der Eng, P, 2001, Food for Growth: Trends in Indonesia's Food Supply 18801995, Journal of Interdisciplinary History, XXX: 4, hIm. 190.

8 Pantjar Simatupang, 1999, Toward Sustainable Food Security: The Need for A New Paradigm, ACIAR Indonesia Research Project, hlm. 33. beras, baik pemerintah pusat maupun pemerintah daerah. UUD 1945 telah menyebutkan dalam Pasal 18 ayat (1) bahwa Negara Kesatuan Republik Indonesia dibagi atas daerah-daerah provinsi dan daerah provinsi itu dibagi atas kabupaten dan kota, yang tiap-tiap provinsi, kabupaten, dan kota itu mempunyai pemerintahan daerah, yang diatur dengan undang-undang; ayat (2) meyebutkan Pemerintahan daerah provinsi, daerah kabupaten, dan kota mengatur dan mengurus sendiri urusan pemerintahan menurut asas otonomi dan tugas pembantuan; ayat (3) menyebutkan Pemerintahan daerah provinsi, daerah kabupaten, dan kota memiliki Dewan Perwakilan Rakyat Daerah yang anggotaanggotanya dipilih melalui pemilihan umum; dan ayat (4) menyebutkan Gubernur, Bupati, dan Walikota masing-masing sebagai kepala pemerintah daerah provinsi, kabupaten, dan kota dipilih secara demokratis. ${ }^{9}$

9 M. Rendi Aridhayandi, 2016, Optimalisasi Peran Pemerintah Daerah Dalam Perlindungan Anak Korban Kekerasan Seksual (Kajian Perpu RI No. 1 Tahun 2016 tentang Perubahan Kedua Atas UU No. 23 


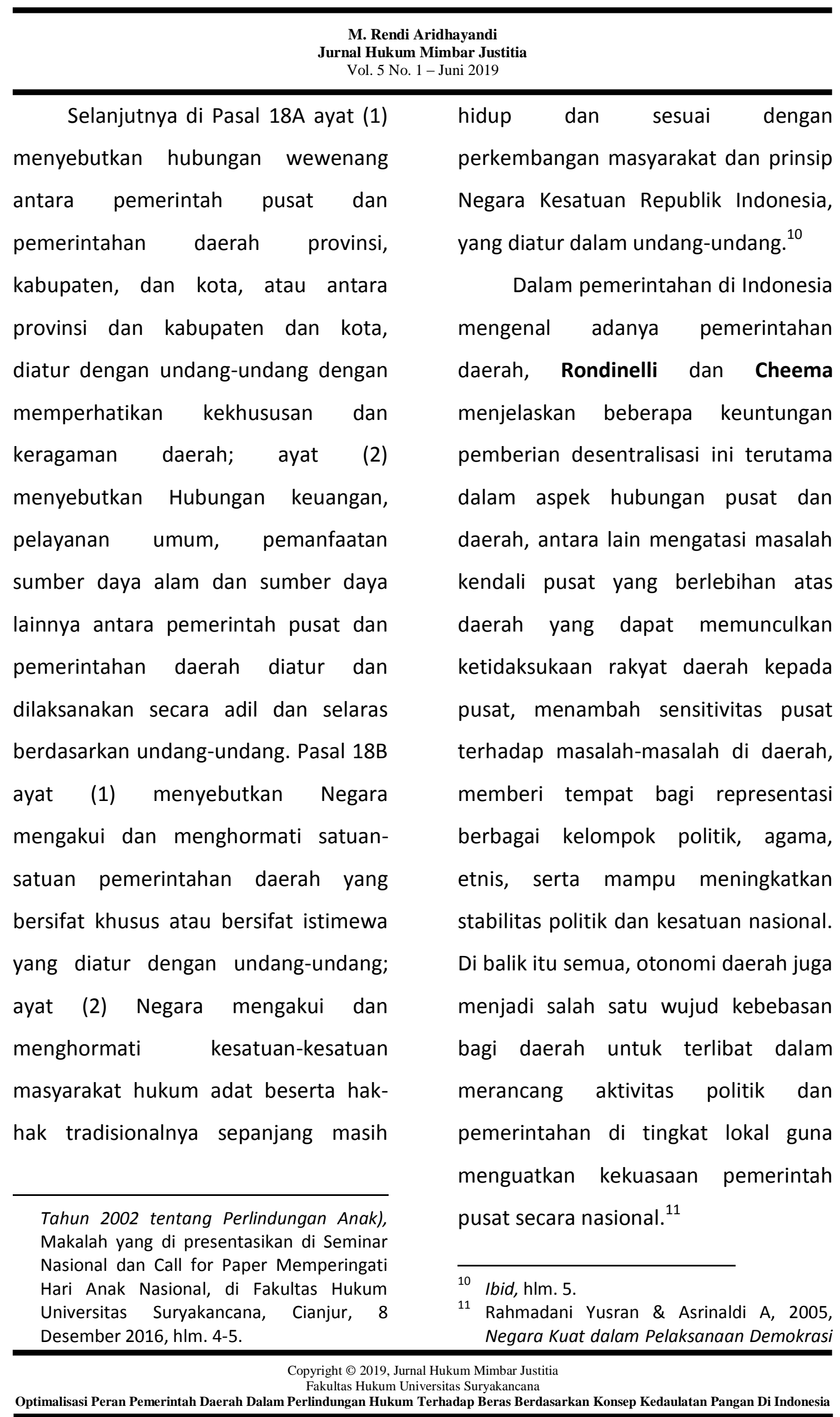




\begin{tabular}{|c|c|}
\hline $\begin{array}{r}\text { M. } \\
\text { Jurnal } \\
\text { Vol. }\end{array}$ & \\
\hline $\begin{array}{l}\text { Dengan demikian peran } \\
\text { pemerintah daerah sangat penting } \\
\text { untuk urusan ketersediaan beras } \\
\text { dengan adanya kewenangan otonomi } \\
\text { daerah. Pemerintah daerah dengan } \\
\text { otonomi daerah dapat secara bebas } \\
\text { untuk mendesain suatu wilayahnya } \\
\text { guna mendukung pemerintah pusat } \\
\text { menuju ketahanan pangan. Namun } \\
\text { perlu diingat, bahwa ketahanan pangan } \\
\text { bukan persoalan produksi semata }\end{array}$ & $\begin{array}{l}\text { pada Repelita } 3 \text { dan } 4 \text {, hasilnya sempat } \\
\text { dirasakan pada tahun } 1984 \text { di mana } \\
\text { Indonesia mencapai level swasembada } \\
{\text { pangan. }{ }^{13} \text { Namun saat ini Indonesia }}^{\text {sedang di hadapi dengan tantangan. }} \\
\text { Karena dalam Undang-Undang No. } 18 \\
\text { tahun } 2012 \text { tentang Pangan, persoalan } \\
\text { pangan ditujukan untuk mencapai tiga } \\
\text { hal sekaligus yaitu kedaulatan pangan, } \\
\text { kemandirian pangan, dan katahanan } \\
\text { pangan. }\end{array}$ \\
\hline
\end{tabular}

tetapi lebih soal management investasi pada sektor-sektor non pangan dan non-pertanian dilihat sebagai bagian integral dari pencapaian ketahanan pangan. Setidaknya, ini konsisten dengan argumen Amarya Sen bahwa produksi pangan bukan determinan tunggal ketahanan pangan, melainkan hanyalah salah satu faktor penentu. ${ }^{12}$ Indonesia sempat mengalami swasembada pangan. Orde Baru sempat mengganti orientasi kebijakan pangan dari swasembada beras ke swasembada pangan secara umum

Lokal di Indonesia: Tinjauan awal terhadap Pemberlakuan Undang-undang Nomor 32 Tahun 2004, Jurnal Demokrasi, Vol. IV, No. 2, hlm. 88.

12 Jonatan Lassa, 2005, Politik Ketahanan Pangan Indonesia 1950-2005, ZEF, Jakarta, hlm. 8.

\section{PEMBAHASAN \\ a. Swasembada Pangan $\neq$ Ketahanan Pangan.}

Indonesia berkomitmen untuk mencapai swasembada beras di mulai dari Program Kesejahteraan Kasimo (1952-1956); Program Sentra Padi (1956-1965), hingga Repelita. Fakta menunjukan bahwa produksi pangan Indonesia tahun 2004 mampu memberikan hasil yang menggembirakan, ${ }^{14}$ tapi disayangkan bahwa Indonesia tidak mampu mencapai ketahanan pangan yang memadai. Peristiwa kelaparan dan

$\begin{array}{ll}13 & \\ 14 & \text { Ibid, hlm. } 5 . \\ & \text { FAO, Food Outlook, April } 2004 .\end{array}$ 


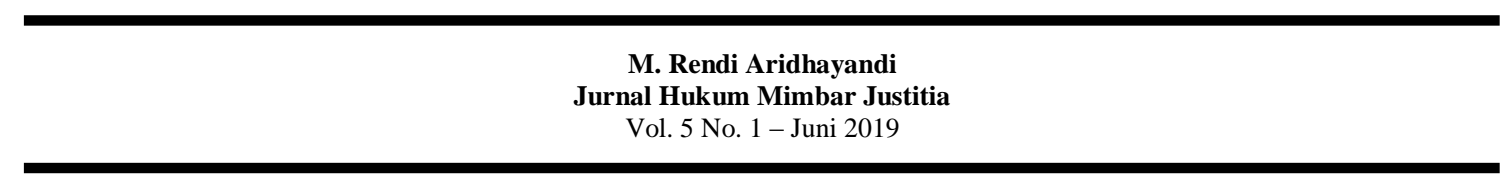

malnutrisi di berbagai tempat di Indonesia menunjukan hal ini. ${ }^{15}$

Swasembada dapat diartikan sebagai kemampuan untuk memenuhi segala kebutuhan. Swasembada pangan adalah keadaan dimana suatu Negara dapat memenuhi tingkat permintaan akan suatu bahan pangan sendiri tanpa perlu melakukan impor dari pihak luar atau daerah lain. ${ }^{16}$

Definisi ketahanan pangan dalam Undang-Undang No. 18 tahun 2012 tentang Pangan yaitu kondisi terpenuhinya Pangan bagi negara sampai dengan perseorangan, yang tercermin dari tersedianya Pangan yang cukup, baik jumlah maupun mutunya, aman, beragam, bergizi, merata, dan terjangkau serta tidak bertentangan dengan agama, keyakinan, dan budaya masyarakat, untuk dapat hidup sehat, aktif, dan produktif secara berkelanjutan.

15 Jonatan Lassa, 2005, Politik Ketahanan Pangan..., Op.Cit, hlm. 7.

16 Gusnatika Putri dan Khairul Anwar, 2014, Kepentingan Pemerintah Daerah Dalam Pencapaian Swasembada Beras Di Kabupaten Siak Tahun 2012, Jurnal Online Mahasiswa (JOM) Bidang IImu Sosial dan IImu Politik, Fakultas IImu Sosial Dan IImu Politik Universitas Riau, Vol. 1, No. 2, hlm. 7.
Stevens memberikan ilustrasi yang membedakan secara tegas antara swasembada pangan dengan ketahanan pangan. Sebagai contohnya Bostwan negara dengan pendapatan perkapita sedang tapi mengalami defisit pangan yang kronis karena minimnya lahan pertanian. Strategi ketahanan pangan nasionalnya adalah swasembada tetapi akhirnya lebih berorientasi pada "self-reliance", yang mana secara formal mengesahkan kontribusi yang hakiki dari pangan import terhadap ketahanan pangan nasional. ${ }^{17}$ 


\begin{tabular}{|c|c|c|}
\hline & & $\begin{array}{r}\text { M. Ren } \\
\text { Jurnal Huk } \\
\text { Vol. } 5 \mathrm{~N}\end{array}$ \\
\hline \multicolumn{3}{|c|}{$\begin{array}{c}\text { Ketahanan Pangan versus Swasembada } \\
\text { Pangan. }\end{array}$} \\
\hline Kategori & $\begin{array}{l}\text { Ketahanan } \\
\text { Pangan }\end{array}$ & $\begin{array}{l}\text { Ketidaktahanan } \\
\text { Pangan }\end{array}$ \\
\hline \multirow{2}{*}{$\begin{array}{l}\text { Swasembada } \\
\text { Pangan }\end{array}$} & A & $B$ \\
\hline & $\begin{array}{l}\text { Contoh: } \\
\text { USA, } \\
\text { Kanada, } \\
\text { Australia, } \\
\text { Brunei }\end{array}$ & $\begin{array}{l}\text { Contoh: } \\
\text { Indonesia, } \\
\text { Filipina dan } \\
\text { Myanmar }\end{array}$ \\
\hline \multirow{2}{*}{$\begin{array}{c}\text { Tidak } \\
\text { Swasembada } \\
\text { Pangan }\end{array}$} & $C$ & D \\
\hline & $\begin{array}{c}\text { Contoh: } \\
\text { Singapura, } \\
\text { Norwegia } \\
\text { dan } \\
\text { Jepang }\end{array}$ & $\begin{array}{c}\text { Contoh: } \\
\text { Malawi, } \\
\text { Eritrea, } \\
\text { Kenya, Kongo, } \\
\text { East Timor }\end{array}$ \\
\hline
\end{tabular}

Negara-negara kategori A (USA, Kanada, Australia, Brunei) memiliki kapasitas pangan yang paling kuat karena memiliki kondisi pangan ideal di mana mereka mampu berswasembada pangan tetapi sekaligus juga memiliki ketahanan pangan yang kuat. Sedangkan Negara C seperti Singapura, Norwegia dan Jepang, mereka sama sekali tidak swasembada pangan tetapi memiliki fondasi ketahanan pangan

18 Dikembangkan dari Stevens, C., Greenhill, R., Kennan, J., \& Devereux S, The WTO Agreement on Agriculture and Food Security, Commonwealth Secretariat, 2000, $\mathrm{hlm}$. 3. dikutip kembali oleh Jonatan Lassa, Idem. yang jauh lebih kuat dari Negaranegara kategori B seperti Indonesia, Filipina dan Myanmar.

Terlihat secara jelas bahwa Negara-negara kategori B mampu mencapai swasembada pangan tetapi mengalami ketidaktahanan pangan. Indonesia mampu berswasembada pangan. Ini jelas terlihat ketika Indonesia mencapai swasembada beras tahun 1984, justru jumlah bantuan pangan USA pada waktu yang sama adalah rata-rata tigapuluh kali lebih besar ketimbang dekade 90an, ketika Indonesia tidak lagi memegang predikat swasembada pangan nasional. Jelaslah bahwa swasembada tingkat nasional tidak serta merta menjawab persoalan distribusi pangan dan akses atas pangan secara adil dan merata. Negara-negara kategori D adalah yang paling rentan karena disamping tidak memiliki kapasitas produksi untuk berswasembada, juga tidak mampu menciptakan ketahanan pangan. Solusi buat negara-negara seperti ini adalah intervensi bantuan pangan internasional. ${ }^{19}$

19 Jonatan Lassa, Idem. 


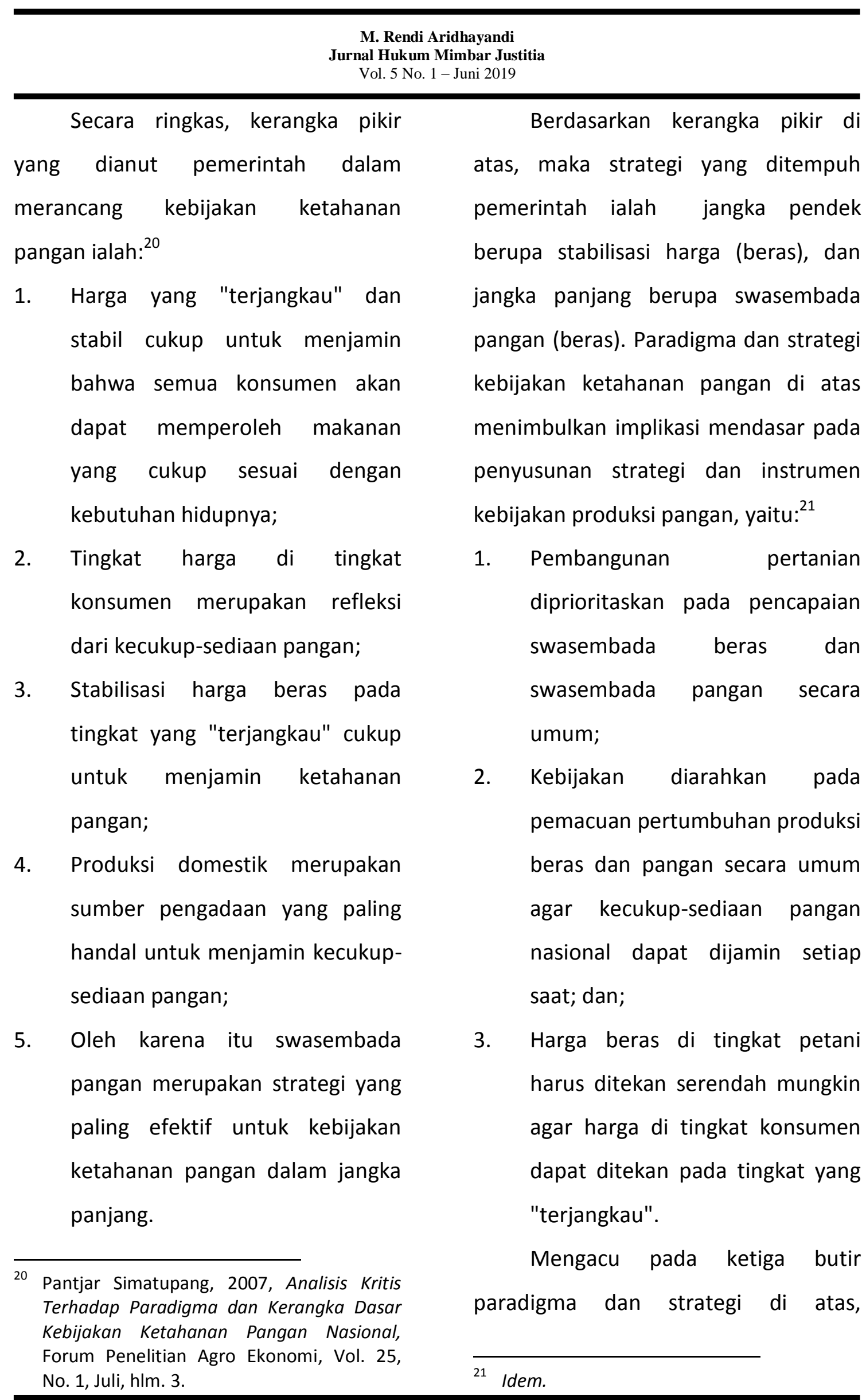




\begin{abstract}
kebijakan produksi pangan terfokus pada pengadaan pangan nasional dan praktis mengabaikan kesejahteraan petani. Petani hanyalah salah satu instrumen esensial dalam rangka pemantapan ketahanan pangan. ${ }^{22}$
\end{abstract}

M. Rendi Aridhayandi

Jurnal Hukum Mimbar Justitia

Vol. 5 No. 1 - Juni 2019

\section{b. Kedaulatan Pangan Sebagai}

Pondasi Ketahanan Pangan.

Berdikari (berdiri di atas kaki sendiri) atau self-sufficient yang ditempuh negara-negara berkembang anggota Non-Blok agar tidak terperosok ke dalam pengaruh Blok Barat maupun Blok Tirnur. Sebagai salah satu penggagas Gerakan Non-Blok, Presiden Soekarno dengan tegas menetapkan "Berdikari" sebagai garis kebijakan politik maupun ekonomi semasa pemerintahan Orde Lama. Sebagai salah satu isu paling strategis dalam bidang sosial-ekonomi-politik, maka berdikari dalam pengadaan pangan atau swasembada pangan mutlak merupakan garis kebijakan ketahanan pangan yang dianut pemerintah Indonesia semasa Orde Lama. Dengan garis kebijakan ini, impor maupun bantuan pangan asing merupakan sumber ancaman ketahanan pangan, ekonomi maupun politik, sehingga mutlak harus dihindari. ${ }^{23}$

Konsep "Berdikari" (berdiri di atas kaki sendiri) atau self-sufficient ini memiliki kesamaan dalam semangat kedaulatan pangan. Dalam sejarahnya Ketahanan pangan merupakan konsep yang diterima luas di banyak negara dan telah berjalan cukup lama. Konsep "ketahanan pangan" (food security) mulai digodok semenjak akhir tahun 1970-an, sedangkan "kedaulatan pangan" mulai diwacanakan semenjak tahun 1992 atau lebih dari 30 tahun setelahnya. $^{24}$

Definisi kedaulatan pangan dalam Undang-Undang No. 18 tahun 2012 tentang Pangan yaitu hak negara dan bangsa yang secara mandiri menentukan kebijakan Pangan yang menjamin hak atas Pangan bagi rakyat dan yang memberikan hak bagi

23 Ibid, hlm. 6.

24 Syahyuti, Sunarsih, Sri Wahyuni, Wahyuning K.S., dan Miftahul Azis, 2015, Kedaulatan Pangan Sebagai Basis Untuk Mewujudkan Ketahanan Pangan Nasional, Pusat Sosial Ekonomi dan Kebijakan Pertanian, Forum Penelitian Agro Ekonomi, Vol. 33, No. 2, hlm. 3. 
M. Rendi Aridhayandi

Jurnal Hukum Mimbar Justitia

Vol. 5 No. 1 - Juni 2019

masyarakat untuk menentukan sistem Pangan yang sesuai dengan potensi sumber daya lokal.

Jika ditelusuri baris per baris dari seluruh pasal dalam UU Pangan, kata "kedaulatan pangan" muncul sebanyak delapan kali dalam batang tubuh, dan tiga kali dalam Bagian Penjelasan. Pada batang tubuh muncul pada pasal 2, 3, 6, 23 (1), 117, 125, 126, dan 130 (1). Dari keseluruhan kalimat dalam UU ini, kata "kedaulatan pangan" selalu muncul bersama-sama dengan "ketahanan pangan" dan "kemandirian pangan". Ketiganya selalu muncul bersamaan, atau tidak pernah sendirian. Kata "kedaulatan pangan" berada di depan, lalu diikuti dua yang lainnya. Hal ini bisa dimaknai bahwa kedaulatan pangan merupakan hal yang harus dicapai terlebih dahulu, sebagai jalan untuk mencapai tujuan akhirnya yakni "ketahanan pangan". 25

$$
\text { Ide dasar kedaulatan pangan }
$$
adalah mengangkat kesejahteraan petani kecil yang selama ini masih terpinggirkan. Pendekatan kedaulatan pangan lebih menghargai budaya lokal, sehingga petani dapat menanam varietas sendiri yang disukainya, dengan cara sendiri, dan memasak dengan selera sendiri karena menjunjung tinggi prinsip diversifikasi pangan sesuai dengan budaya lokal yang ada. Kedaulatan pangan mendukung sepenuhnya pola-pola pertanian yang berbasis keluarga, dimana mereka menanam sendiri dan memakan sendiri dari lahannya (land to mouth). ${ }^{26}$

Setidaknya ada dua kesamaan antara ketahanan pangan dan kedaulatan pangan, yaitu: ${ }^{27}$

1. keduanya berbicara soal yang sama yakni pangan. Namun, keduanya saling melengkapi, karena batu pijak kedua konsep ini tidaklah sama. Ketahanan pangan lebih menitikberatkan pada ketersediaan pangan bagi rakyat sebagai tujuan akhir dari pembangunan pangan, sedangkan kedaulatan pangan lebih menitikberatkan kemandirian pangan, perlindungan kepada petani dan 


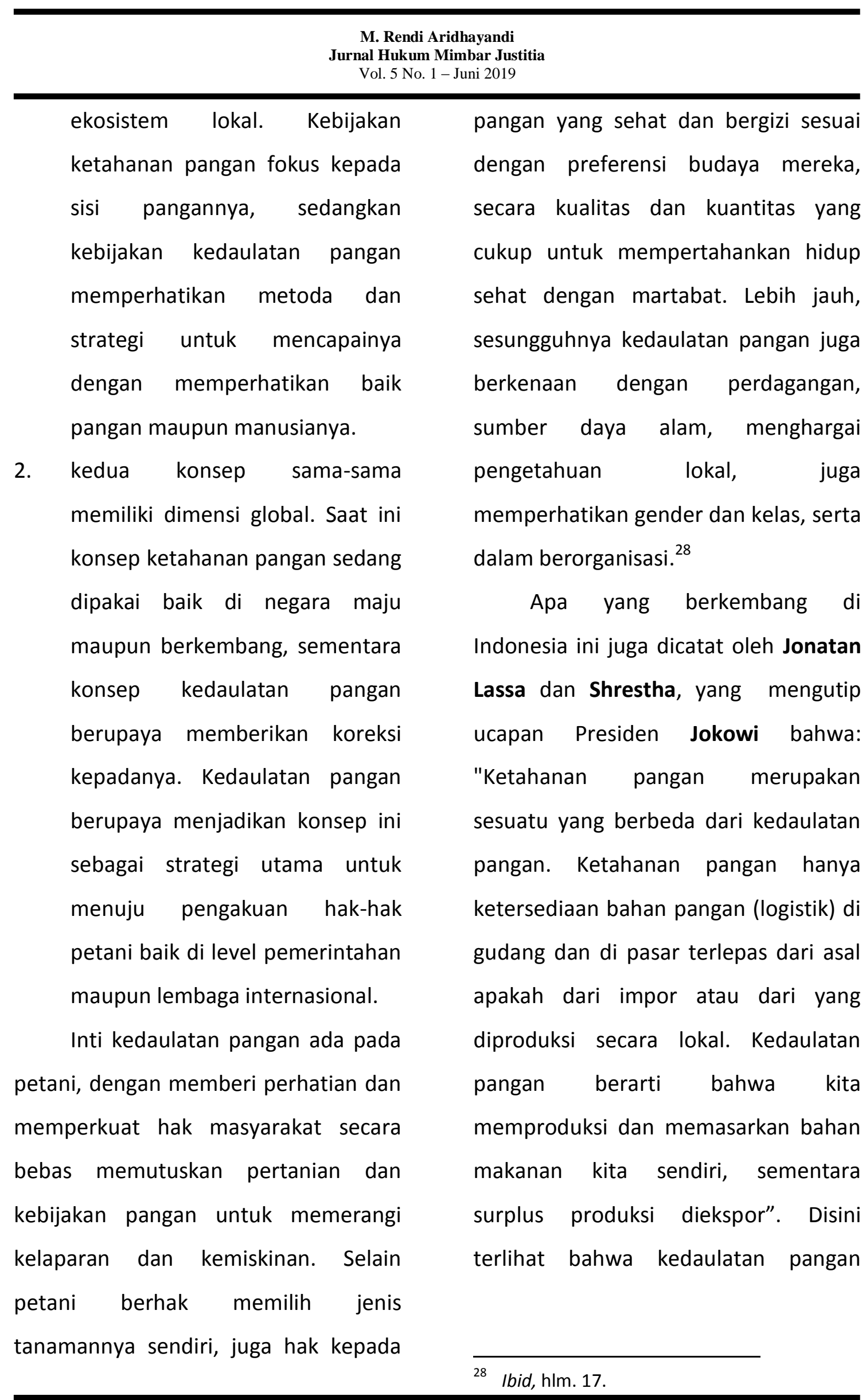


M. Rendi Aridhayandi

Jurnal Hukum Mimbar Justitia

Vol. 5 No. 1 - Juni 2019

bermakna lebih dalam dibanding ketahanan pangan. ${ }^{29}$

c. Optimalisasi Peran Pemerintah Daerah Dalam Mewujudkan Kedaulatan Pangan Terhadap Beras.

Pemerintah daerah dengan kewenangan otonomi daerah setidaknya memiliki 3 (tiga) pedoman untuk mengoptimalkan perannya untuk mewujudkan kedaulatan pangan khususnya terhadap beras, yaitu:

a. Undang-Undang No. 18 tahun 2012 tentang Pangan, yaitu bahwa ada dua pihak terkait kedaulatan pangan yakni: (1) negara yang memiliki hak secara mandiri untuk menentukan kebijakan pangan yang menjamin hak atas pangan bagi rakyat; serta (2) masyarakat yang juga berhak menentukan sistem pangan yang

29 Jonatan Lassa dan Maxim Shrestha, 2014, Food Sovereignty Discourse in Southeast Asia: Helpful or Disruptive?, Rajaratnam School of International Studies, Nanyang Technologicla University, Singapore, www.rsis.edu.sg, dikutip dari Syahyuti, Sunarsih, Sri Wahyuni, Wahyuning K.S., dan Miftahul Azis, 2015, Kedaulatan Pangan Sebagai Basis..., Ibid, hlm. 9. sesuai dengan sumber daya lokal. ${ }^{30}$

b. Dokumen "Nawacita" yang dilontarkan Presiden Joko Widodo dalam visi, misi dan program aksi yang berjudul "Jalan Perubahan Untuk Indonesia Yang Berdaulat, Mandiri Dan Berkepribadian" pada periode Mei 2014 saat kampanye pemilihan presiden. "Nawacita" bermakna sebagai sembilan agenda perubahan. Kedaulatan pangan tercantum secara jelas pada agenda nomor 7

("Mewujudkan Kemandirian

Ekonomi Dengan Menggerakkan sektor-sektor Strategis Ekonomi Domestik"). Dalam cita nomor 7 ini ada lima program yaitu: (1) Membangun kedaulatan pangan, (2) Membangun kedaulatan energi, (3) Membangun kedaulatan keuangan,

Mendirikan bank petani/nelayan dan UMKM termasuk gudang dengan fasilitas pengolahan paska panen di setiap sentra

30 Ibid, hlm. 7. 


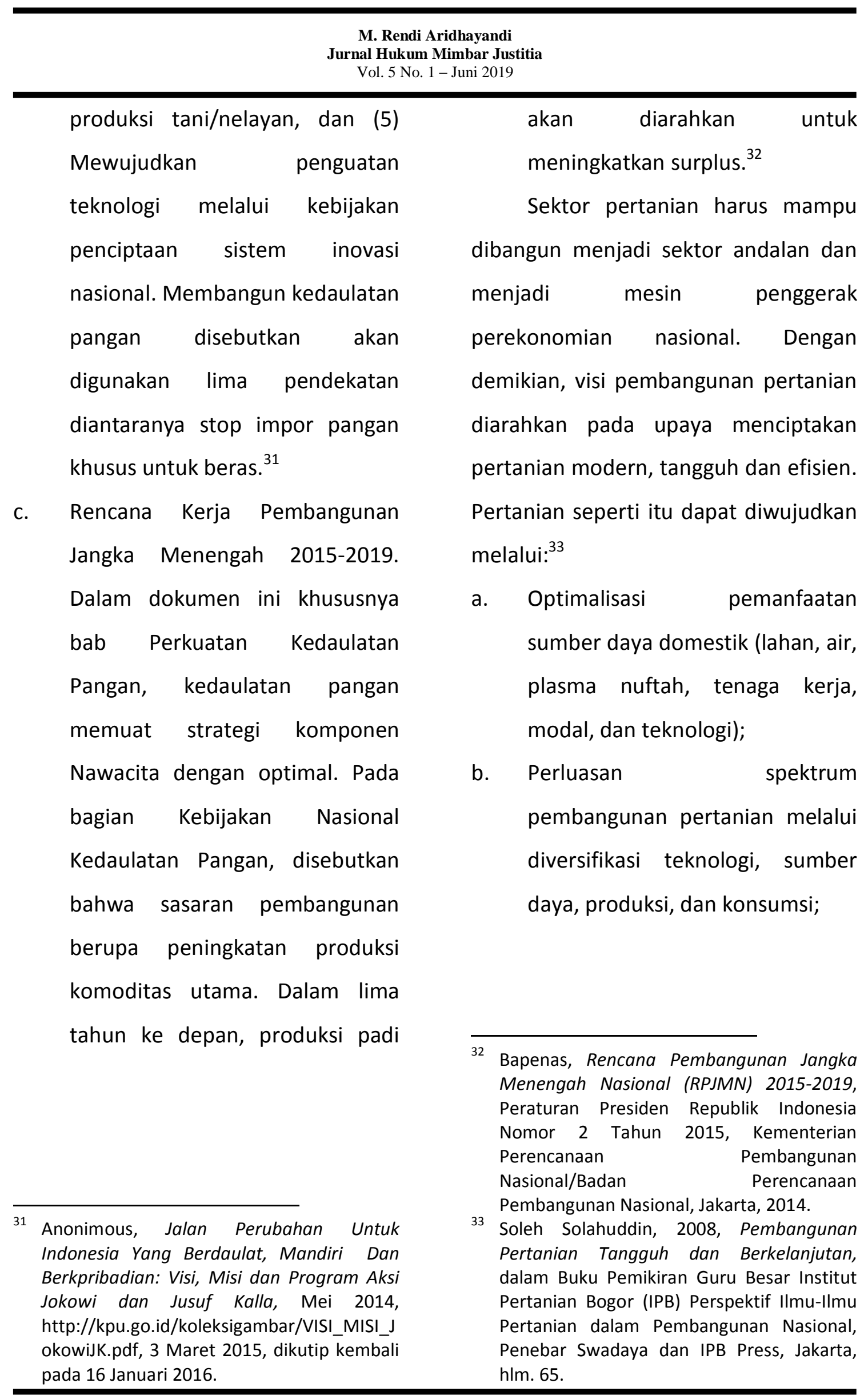




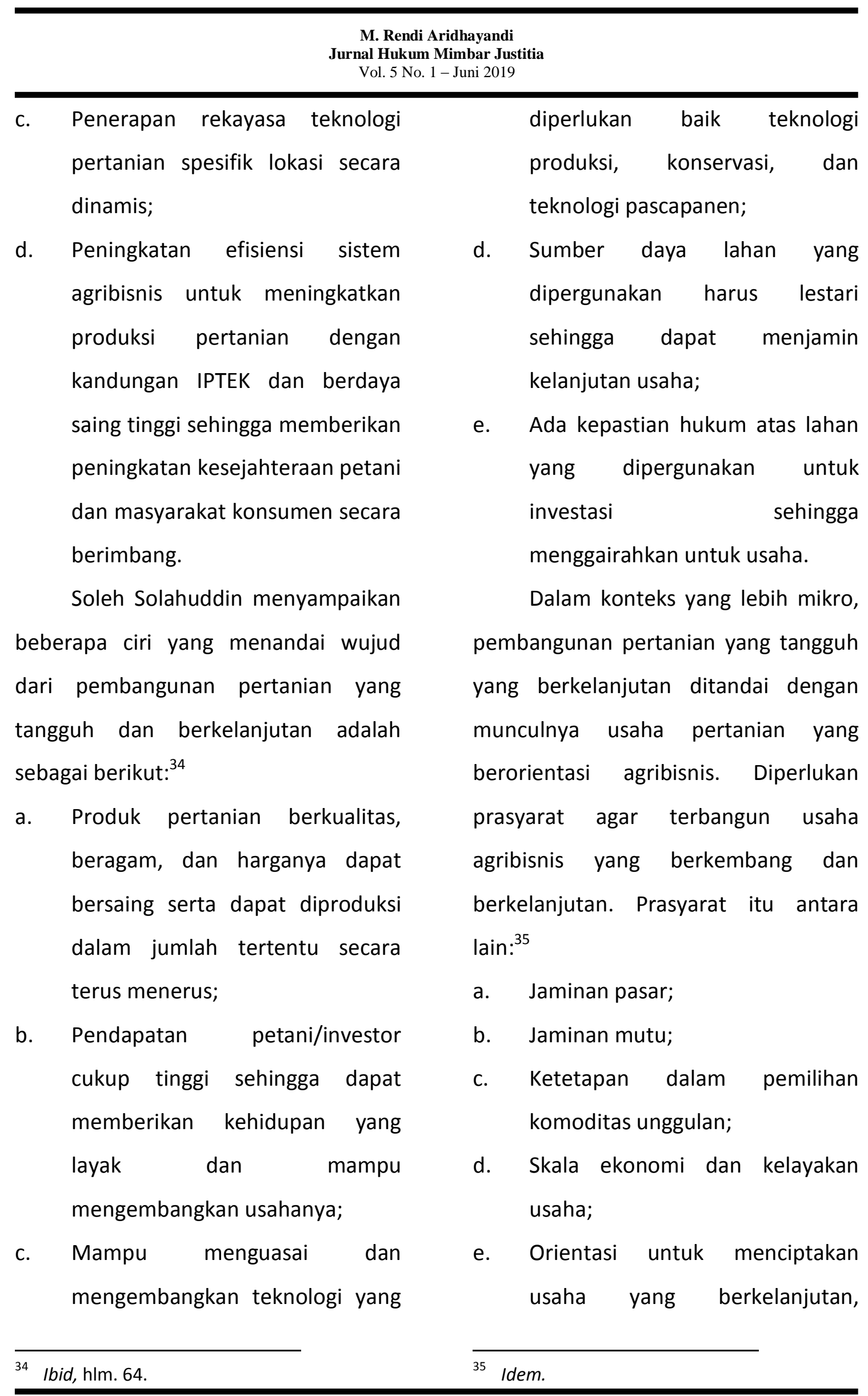




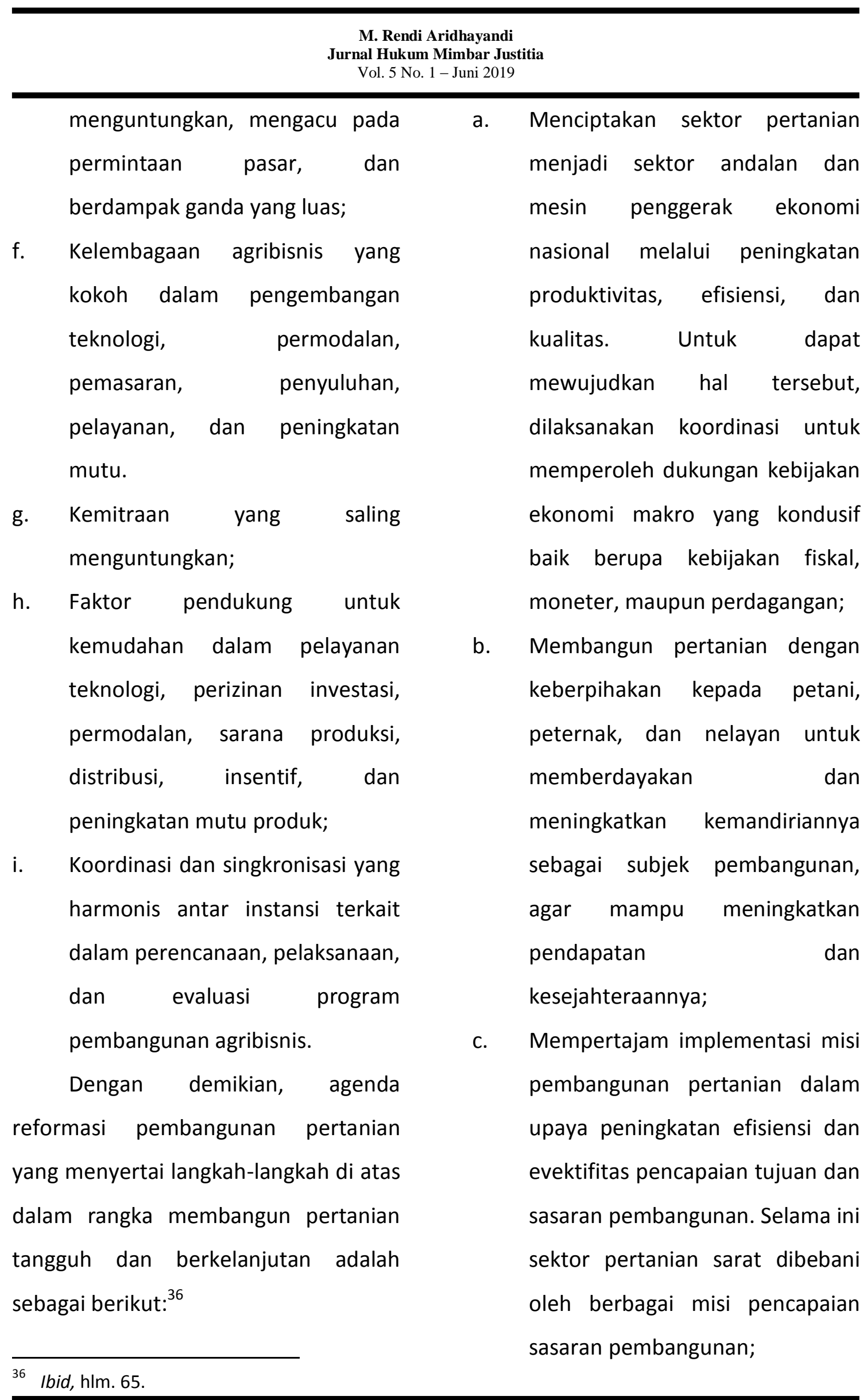


M. Rendi Aridhayandi

Jurnal Hukum Mimbar Justitia

Vol. 5 No. 1 - Juni 2019

d. Meningkatkan keberdayaan petani dan kelembagaan kelompok tani agar mampu secara efektif mengartikulasikan aspirasi dan kepentingan petani. Adanya organisasi petani yang kuat merupakan faktor kunci agar kepentingan petani dapat lebih diakomodasikan dalam kebijakan pembangunan. Organisasi merupakan wahana untuk meningkatkan kemampuan mereka dalam menganalisis masalah dan menentukan secara rasional kegiatan pembangunan pertanian yang tepat dalam pembangunan pertanian;

e. Membangun pertanian dan aparat pertanian untuk dapat memberikan pelayanan yang prima kepada masyarakat, khususnya petani dan nelayan sehingga dapat menumbuhkan iklim kondusif bagi masyarakat untuk berpartisipasi aktif dalam pembangunan pertanian;

f. Mendukung proses demokratisasi dalam pembangunan pertanian melalui langkah revitalisasi kelembagaan dan aparat pertanian di daerah, percepatan pelaksanaan otonomi di bidang pertanian dengan menerapkan perencanaan wilayah sebagai dasar penentuan kegiatan pembangunan pertanian;

g. Meningkatkan keterkaitan subsistem produksi pertanian dengan subsistem lainnya (prasarana, pengolahan, pemasaran/distribusi) dalam kerangka pengembangan agribisnis;

h. Mempertajam orientasi dan arah pengembangan komoditas pertanian dengan mengacu pada dinamika pasar, produk unggulan berdaya saing tinggi, berwawasan lingkungan, dan terintegrasi dengan sektor dan subsistem ekonomi lainnya.

Berkaitan dengan urusan kualitas produksi, kegiatan petani pasca panen itu antara lain adalah melakukan diversifikasi vertikal. Petani di sini melakukan kegiatan pendayagunaan hasil untuk meningkatkan mutu dan nilai tambah produk atau komoditas 


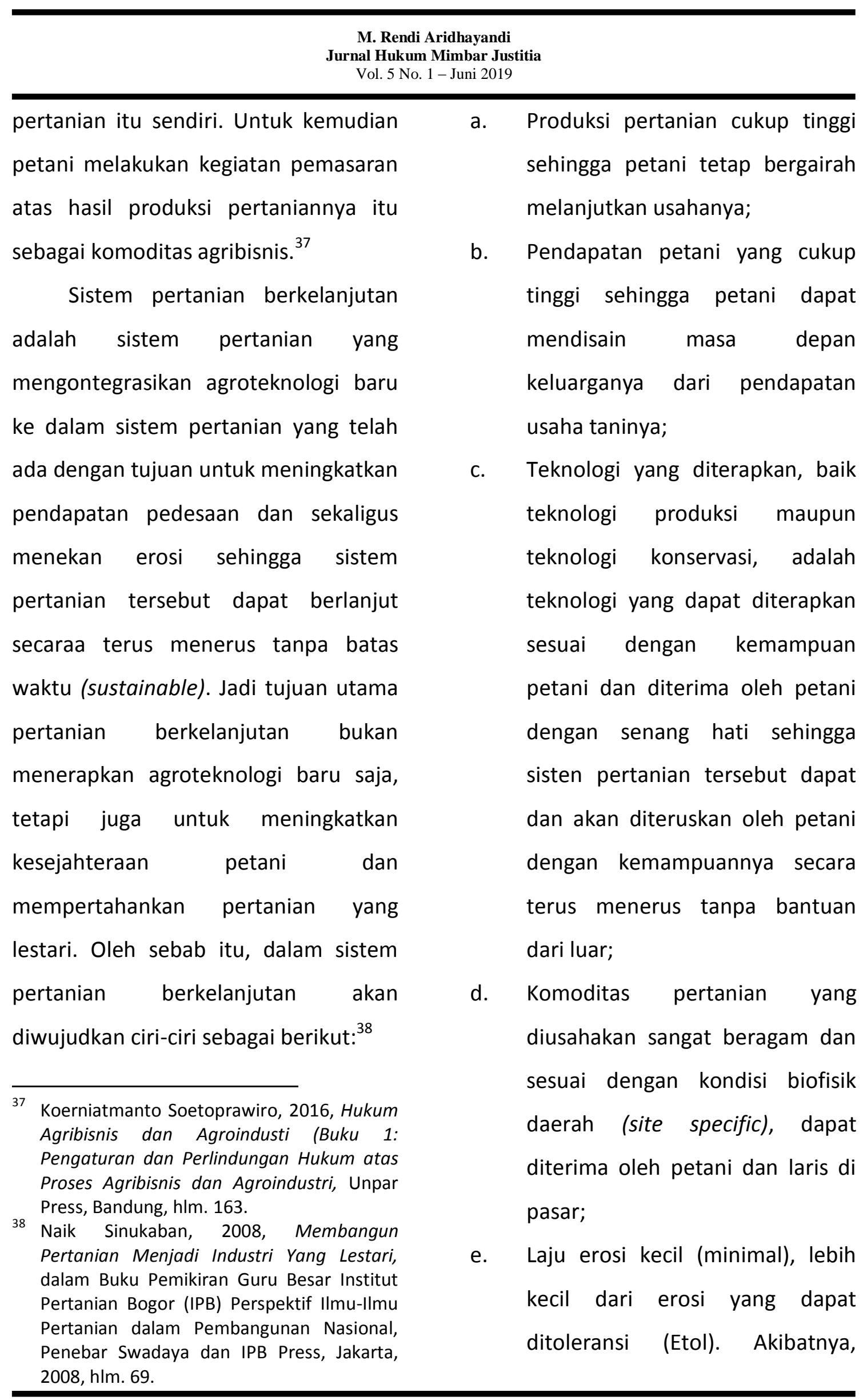




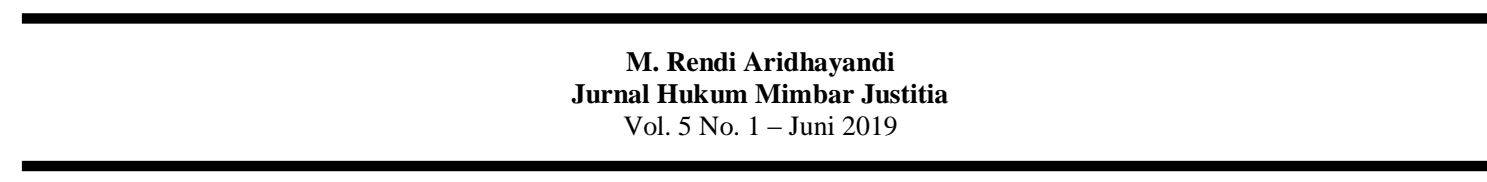

produktivitas yang cukup tinggi tetap dipertahankan/ditingkatkan secara lestari dan fungsi hidrologis daerah terpelihara dengan baik sehingga tidak terjadi banjir di musim hujan dan kekeringan di musim kemarau;

f. Sistem penguasaan/pemilikan lahan dapat menjamin keamanan investasi jangka panjang (longterm investment security) dan menggairahkan petani untuk terus berusaha tani;

g. Meningkatkan lapangan kerja di daerah pedesaan.

Dengan demikian perlunya optimalisasi peran pemerintah daerah dengan kewenangan otonomi daerah, mengingat Indonesia masih memiliki banyak agenda tentang kedaulatan pangan, terutama masalah reforma agararia. Hanya kedaulatan pangan yang berbasiskan pada reforma agraria (genuine agrarian reform) sebagai bekal menghadapi multi krisis ke depan. Menurut Rosset "Kedaulatan pangan adalah satu-satunya cara untuk secara efektif melindungi ekonomi pangan nasional dari tekanan ekternal berupa dumping, penimbunan, dan spekulasi". Menurut Edelman, kedaulatan pangan merupakan terobosan dalam kebijakan pangan secara keseluruhan, karena akan lebih berkeadilan dan berkelanjutan. Kedaulatan pangan melambangkan segala macam gerakan pembebasan dari penindasan, karena kedaulatan pangan berdasarkan kepada saling ketergantungan dan penghargaan terhadap lingkungan hidup. ${ }^{39}$

Upaya perlindungan pemerintah terhadap petani dari gejolak harga beras international tersebut tampaknya masih harus dilakukan mengingat selama dua dekade terakhir masih menunjukkan gejala terjadinya fluktuasi harga internasional dan laju peningkatan harga domestik masih lebih tinggi dari harga pasar internasional. Harga domestik yang cenderung masih lebih tinggi dari harga internasional memang pada satu sisi menguntungkan petani dalam negeri namun pada sisi lain akan terjadi tekanan pasar internasional termasuk

39 Syahyuti, Sunarsih, Sri Wahyuni, Wahyuning K.S., dan Miftahul Azis, 2015, Kedaulatan Pangan Sebagai Basis..., Op.Cit, hlm. 7. 
M. Rendi Aridhayandi

Jurnal Hukum Mimbar Justitia

Vol. 5 No. 1 - Juni 2019

berakibat terjadinya impor ilegal yang terjadi beberapa tahun terakhir. Selain itu, peningkatan konsumsi beras baik yang disebabkan oleh peningkatan jumlah penduduk maupun tingkat konsumsi per kapita akan menyebabkan naiknya permintaan (demand) beras domestik. Meningkatnya permintaan beras domestik dengan laju pertumbuhan yang lebih besar dari produksi domestik akan semakin mendorong naiknya harga beras domestik yang langsung maupun tidak langsung akan memotivasi meningkatnya impor pula. ${ }^{40}$

Tidak kalah penting, pemerintah daerah dalam upaya kedaulatan pangan terhadap beras melakukan suatu langkah mengangkat budaya lokal, contohnya beras Pandanwangi Cianjur yang memiliki kekhasan, yaitu rasanya yang enak, pulen dan beraroma khas pandan. Untuk menghasilkan Beras Pandanwangi Cianjur yang bercita rasa khas, padi

40 Dwidjono H. Darwanto, 2005, Ketahanan Pangan Berbasis Produksi dan Kesejahteraan Petani, IImu Pertanian, Vol. 12, No. 2, agrisci.ugm.ac.id, hlm. 159. varietas Pandanwangi hanya dapat ditanam di tujuh kecamatan di Kabupaten Cianjur, yaitu Warungkondang, Gekbrong, Cugenang, Cilaku, Cianjur, Cibeber, dan Campaka. Apabila varietas padi Pandanwangi ditanam diluar ketujuh kecamatan tersebut atau di daerah lain, maka kekhasan berasnya akan hilang terutama tekstur pulen dan aroma pandannya. ${ }^{41}$ Optimalisasi pemerintah daerah dapat berupa:

a. Reforma agraria (perlindungan lahan dengan melakukan suatu regulasi penataan ruang),

b. Perlindungan hukum kepada petani (dengan membuat regulasi yang tujuannya mensejahterakan petani),

c. Ketersediaan bibit, pupuk dan alat-alat produksi pendukung lainnya;

d. Mendaftarkan merek dan indikasi geografis produk pertanian ke Direktorat Jenderal Kekayaan Intelektual Kementrian Hukum

41 Masyarakat Pelestari Padi Pandanwangi Cianjur (MP3C), 2015, Buku Persyaratan Indikasi Geografis Beras Pandanwangi Cianjur, Kata Pengantar, 2015, hlm. i. 


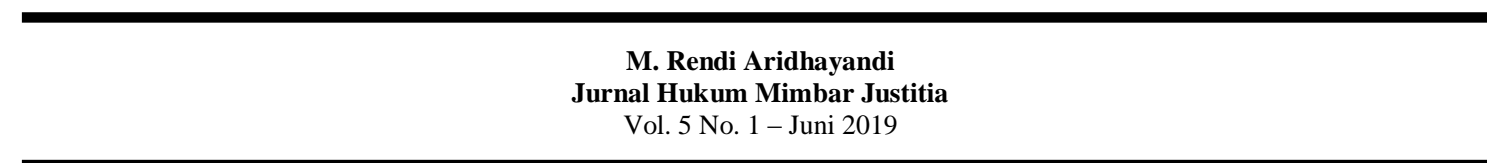

dan Hak Asasi Manusia Republik Indonesia;

e. Pengaturan harga, mutu produk dan pangsa pasar suatu produk pertanian.

\section{PENUTUP}

\section{Kesimpulan}

Peran pemerintah daerah dalam optimalisasi perlindungan hukum terhadap beras berdasarkan konsep kedaulatan pangan di Indonesia menjadi sangat penting ketika sumber daya alam yang melimpah, namun secara pengelolaan tidak di kelola dengan baik. Beras yang merupakan pangan pokok di Indonesia harus terus menjadi skala prioritas. Hal ini sesuai dengan definisi kedaulatan pangan dalam Undang-Undang No. 18 tahun 2012 tentang Pangan yaitu hak negara dan bangsa yang secara mandiri menentukan kebijakan Pangan yang menjamin hak atas Pangan bagi rakyat dan yang memberikan hak bagi masyarakat untuk menentukan sistem Pangan yang sesuai dengan potensi sumber daya lokal.
Dengan kewenangan yang dimiliki oleh pemerintah daerah yaitu dengan otonomi daerah, maka kebijakan dapat dioptimalkan. Khususnya di bidang hukum, pemerintah daerah dapat membuat regulasi berupa peraturan daerah (perda) yang bertujuan untuk kedaulatan pangan terhadap beras.

\section{Saran}

Sebaiknya pemerintah daerah fokus untuk mewujudkan kedaulatan pangan terhadap beras di Indonesia, karena pemerintah pusat akan butuh peran besar pemerintah daerah sebagai pelaksana yang tahu persis kondisi di daerah. Dengan terus bertambahnya jumlah penduduk, maka akan semakin bertambahnya kebutuhan akan pangan, khususnya terhadap beras yang merupakan pangan pokok masyarakat Indonesia. Pemerintah daerah harus sadar dan paham betul faktor utama pertanian adalah lahan, oleh karena itu pengadaan lahan pertanian khususnya terhadap padi jangan sampai teralih fungsi dengan kebutuhan lainnya seperti perumahan, industri, pusat perbelanjaan dll 


\section{DAFTAR PUSTAKA}

\section{A. Buku}

Bapenas, Rencana Pembangunan Jangka Menengah Nasional (RPJMN) 2015-2019, Peraturan Presiden Republik Indonesia Nomor 2 Tahun 2015, Kementerian Perencanaan Pembangunan Nasional/Badan Perencanaan Pembangunan Nasional, Jakarta, 2014.

Koerniatmanto Soetoprawiro, 2016, Hukum Agribisnis dan Agroindusti (Buku 1: Pengaturan dan Perlindungan Hukum atas Proses Agribisnis dan Agroindustri, Unpar Press, Bandung.

Masyarakat Pelestari Padi Pandanwangi Cianjur (MP3C), 2015, Buku Persyaratan Indikasi Geografis Beras Pandanwangi Cianjur, Kata Pengantar.

Muhamad Khumaidi, 2008, Beras Sebagai Pangan Pokok Utama Bangsa Indonesia, Keunikan dan Tantangannya dalam Buku Pemikiran Guru Besar Institut Pertanian Bogor (IPB) Perspektif Ilmu-Ilmu Pertanian dalam Pembangunan Nasional, Penebar Swadaya dan IPB Press, Jakarta.

Naik Sinukaban, 2008, Membangun Pertanian Menjadi Industri Yang Lestari, dalam Buku Pemikiran Guru Besar Institut Pertanian Bogor (IPB) Perspektif Ilmu-Ilmu Pertanian dalam Pembangunan Nasional, Penebar Swadaya dan IPB Press, Jakarta.
Soleh Solahuddin, 2008, Pembangunan

Pertanian Tangguh dan

Berkelanjutan, dalam Buku

Pemikiran Guru Besar Institut Pertanian Bogor (IPB) Perspektif Ilmu-Ilmu Pertanian dalam Pembangunan Nasional, Penebar Swadaya dan IPB Press, Jakarta.

\section{B. Peraturan Perundang-Undangan} Undang-Undang Dasar 1945.

Undang-Undang No. 18 tahun 2012 tentang Pangan

\section{Jurnal, Skripsi, Tesis, Internet}

Anonimous, Jalan Perubahan Untuk Indonesia Yang Berdaulat, Mandiri Dan Berkpribadian: Visi, Misi dan Program Aksi Jokowi dan Jusuf Kalla, Mei 2014, http://kpu.go.id/koleksigambar/V ISI_MISI_JokowiJK.pdf, 3 Maret 2015, dikutip kembali pada 16 Januari 2016.

Dwidjono H. Darwanto, 2005, Ketahanan Pangan Berbasis Produksi dan Kesejahteraan Petani, Ilmu Pertanian, Vol. 12, No. 2, agrisci.ugm.ac.id.

FAO, Food Outlook, April 2004.

Gusnatika Putri dan Khairul Anwar, 2014, Kepentingan Pemerintah Daerah Dalam Pencapaian Swasembada Beras Di Kabupaten Siak Tahun 2012, Jurnal Online Mahasiswa (JOM) Bidang IImu Sosial dan Ilmu Politik, Fakultas 


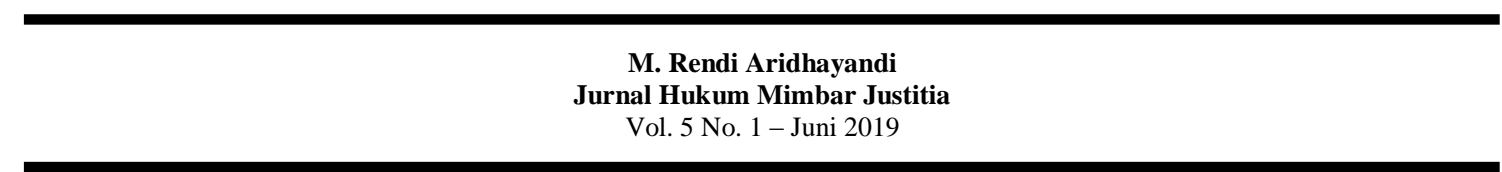

IImu Sosial Dan Ilmu Politik Universitas Riau, Vol. 1, No. 2.

Jonatan Lassa dan Maxim Shrestha, Food Sovereignty Discourse in Southeast Asia: Helpful or Disruptive?, 2014, Rajaratnam School of International Studies, Nanyang Technologicla University, Singapore, www.rsis.edu.sg.

Jonatan Lassa, 2005, Politik Ketahanan Pangan Indonesia 1950-2005, ZEF, Jakarta.

M. Rendi Aridhayandi, 2016, Optimalisasi Peran Pemerintah Daerah Dalam Perlindungan Anak Korban Kekerasan Seksual (Kajian Perpu RI No. 1 Tahun 2016 tentang Perubahan Kedua Atas UU No. 23 Tahun 2002 tentang Perlindungan Anak), Makalah yang di presentasikan di Seminar Nasional dan Call for Paper Memperingati Hari Anak Nasional, di Fakultas Hukum Universitas Suryakancana, Cianjur, 8 Desember 2016.

Pantjar Simatupang, 2007, Analisis Kritis Terhadap Paradigma dan Kerangka Dasar Kebijakan Ketahanan Pangan Nasional, Forum Penelitian Agro Ekonomi, Vol. 25, No. 1, Juli.
Pantjar Simatupang, 1999, Toward Sustainable Food Security: The Need for A New Paradigm, ACIAR Indonesia Research Project.

Rahmadani Yusran \& Asrinaldi A, 2005, Negara Kuat dalam Pelaksanaan Demokrasi Lokal di Indonesia: Tinjauan awal terhadap Pemberlakuan Undang-undang Nomor 32 Tahun 2004, Jurnal Demokrasi, Vol. IV, No. 2.

Roosganda Elizabeth, 2008, Peran Ganda Wanita Tani dalam Mencapai Ketahanan Pangan Rumah tangga di Pedesaan, Puslitbang Tanaman Pangan, Buletin Iptek Tanaman Pangan Vol. 3, No. 1.

Stevens, C., Greenhill, R., Kennan, J., \& Devereux S, 2000, The WTO Agreement on Agriculture and Food Security, Commonwealth Secretariat.

Syahyuti, Sunarsih, Sri Wahyuni, Wahyuning K.S., dan Miftahul Azis, 2015, Kedaulatan Pangan Sebagai Basis Untuk Mewujudkan Ketahanan Pangan Nasional, Pusat Sosial Ekonomi dan Kebijakan Pertanian, Forum Penelitian Agro Ekonomi, Vol. 33, No. 2.

Van der Eng, P, 2001. Food for Growth: Trends in Indonesia's Food Supply 1880-1995, Journal of Interdisciplinary History, XXX: 4. 